\title{
Development and evaluation of a smart packaging for the monitoring of ricotta cheese spoilage
}

\begin{abstract}
Colorimetric Smart packaging pH indicator offers a potential use that could allow consumer evaluation of the food quality. In this study, it was developed a film based on chitosan, gelatin, PVA and red cabbage extract for food quality monitoring. Films were characterized by Thickness and swelling index. Proof-of-Concept application tests were conducted with Ricotta cheese for evaluated the potential use in the food spoilage. The results show that indicator film has high hydration capacity and during application in cheese, the film did not visually indicated color change after 7 days refrigeration storage.
\end{abstract}

Keywords: $\mathrm{pH}$ indicator film, natural pigment, ricotta cheese

\author{
Volume I Issue I - 2015
}

\author{
Lidyane Mendes Bento, Mayra Cristina \\ Pereira da Silva, Karina da Silva Chaves, \\ Ricardo Stefani
}

Universidade Federal de Mato Grosso (UFMT), Brazil

\begin{abstract}
Correspondence: Ricardo Stefani, Universidade Federal de Mato Grosso (UFMT), Campus Universitário do Araguaia (CUA), Rodovia BR-070, Km 5, Barra do Garças 78600-000, MT, Brazil, Mato Grosso MT, Brazil, Tel +55 66 3405-53 I7, Fax +55 66 3402-II09, Email rstefani@ufmt.br
\end{abstract}

Received: May 01, 2015 | Published: May 27, 2015

\section{Introduction}

Food packaging technology is constantly evolving in response to growing challenges of a modern society, that search for more healthy and safe food, but with durability and convenience..$^{1,2}$ In this context, the smart packaging is one of the most dynamic technologies used to monitor the condition of the packed food or the environment surrounding the food. ${ }^{1,3}$ This packaging represents an important evolution food industry by provide information about hazard analysis critical control point (HACCP) and consumers knowing what they are buying. Once smart packaging system is able of indicating inform about a change occurred in a product, such as temperature and $\mathrm{pH}$ by means of visual changes. ${ }^{1}$ Thus, a packaging system color based $\mathrm{pH}$ indicator offer a potential use could allow consumer evaluation of the quality food before purchasing or opening the package. ${ }^{4}$ Renewable sources, biopolymer and natural pigments for example, may be used as alternative for intelligent packaging. The employment of bio-based materials for the development of biodegradable films has generated significant interest in industry for being sustainable, renewable, abundant sources, friendliness to the environment, and potential to substitute for petrochemicals. ${ }^{5-7}$

Anthocyanins represent a large group of natural pigments from vegetable sources have great potential as an indicator of food spoilage in intelligent packaging systems, due the color instability of anthocyanins is influenced by its structure, $\mathrm{pH}$, temperature, co-pigmentation, $\mathrm{UV}$ radiation, and presence of oxygen resulting different color. ${ }^{8}$ Yoshida et al. ${ }^{9}$ developed a $\mathrm{pH}$ indicator biodegradable film based on chitosan and containing grape as a $\mathrm{pH}$ indicator. Pereira $\mathrm{Jr}$ et al. ${ }^{10}$ developed a colorimetric temperature-time indicator film for monitoring food quality using chitosan/PVA blend containing anthocyanin applied in milk. Silva-Pereira et al. ${ }^{11}$ development a $\mathrm{pH}$ indicator biodegradable film based on chitosan and starch containing red cabbage extract as a $\mathrm{pH}$ indicator for monitoring fish spoilage. Ricotta is a soft Italian cheese, unripened and obtained by a combination of heat and acid. It can be produced using cheese whey, milk or a mixture of both. This cheese has high moisture content, and its initial $\mathrm{pH}$ is above 6.0, thus it is highly perishable and has a limited shelf-life even under refrigeration due to textural changes and mold growth. ${ }^{12,13}$ The present study aimed to development $\mathrm{pH}$ indicators film based on detection of chemical changes associated with microbial growth in Ricotta cheese during refrigerated storage.

\section{Materials and methods}

\section{Extract preparation}

Red Cabbage (Brassica oleraceae) extract was prepared according to Fuleki and Francis, ${ }^{14}$ with modifications. A sample of approximately $150.0 \mathrm{~g}$ of red cabbage was crushed and macerated with $80 \mathrm{~mL}$ of ethanol-water (7:3). The $\mathrm{pH}$ of the sample was adjusted to 2.0 with $\mathrm{HCl}(1 \mathrm{M})$. Subsequently, the material was stored at $5^{\circ} \mathrm{C}$ for $24 \mathrm{~h}$, protected from light. After this period, the material was filtered and the extract was centrifuged at $103 \mathrm{xg}$ for $10 \mathrm{~min}$. The supernatant was filtered on Whatman paper $n^{\circ} 1$ and the resulting extract was used for $\mathrm{pH}$ indicator film.

\section{Preparation of the $\mathrm{pH}$ indicator film}

A chitosan hydrogel was prepared by dissolving $1 \mathrm{~g}$ of chitosan (Sigma-Aldrich Art No.448877, 80\% deacetylated) in $100 \mathrm{~mL}$ of aqueous acetic acid $1 \%(\mathrm{v} / \mathrm{v})$ under magnetic stirring for $24 \mathrm{~h}$ at room temperature $\left(25^{\circ} \mathrm{C}\right)$. The PVA hydrogel was prepared by dissolving $1 \mathrm{~g}$ of polymer powder (Sigma-Aldrich Art. No. 363146, 99\% Hydrolyzed) in $100 \mathrm{~mL}$ of distilled water under magnetic stirring at $70 \pm 2^{\circ} \mathrm{C}$ until complete dissolution had occurred. Gelatin hydrogel was prepared by dissolving $10 \mathrm{~g}$ of gelatin (acquired in local market) in $100 \mathrm{~mL}$ of distilled water under magnetic stirring at $40 \pm 2^{\circ} \mathrm{C}$ until complete dissolution had occurred. After the chitosan/PVA/gelatin ratio of 1.34:0.83:0.83 (v/v) was mixture and, a 1\% solution of sodium tripolyphosphate $\left(\mathrm{Na}_{5} \mathrm{P}_{3} \mathrm{O}_{10}\right) 0.1 \%(\mathrm{w} / \mathrm{v})$ relative to the total volume of the mixture was added to the final hydrogel in order to promote crosslinking. The final chitosan/PVA/gelatin/extract hydrogel was prepared with a casting technique, with incorporation of the $15 \%$ anthocyanin extract of the total volume of the mixture of hydrogels. The hydrogel was casted $(70 \mathrm{ml})$ in Petri $(90 \mathrm{~mm}$ diameter) plates and then placed in an oven at $25^{\circ} \mathrm{C}$ for $72 \mathrm{~h}$ for solvent drying, resulting in the final $\mathrm{pH}$ indicator films. 


\section{Thickness of the film}

Film thickness was measured using digital caliper with precision of $0.02 \mathrm{~mm}$ and repetition precision of $0.01 \mathrm{~mm}$ (Mitutoyo-Digimatic $\AA$, Japan) at five random positions. Results were expressed with mean and standard derivation.

\section{Determination of Swelling Index (Si \%)}

Swelling Index was determined by the method previously described. ${ }^{10}$ Initially, the TTI samples were cut into $4.0 \mathrm{~cm}^{2}$ slices and then the samples were kept in a desiccator with silica-gel for 7days. After this procedure, samples were weighed and then subjected to immersion in beakers containing $250 \mathrm{~mL}$ of distilled water for different time intervals $(0.5,1.0,3.0,5.0,7.0$ and $10.0 \mathrm{~min})$ at room temperature $\left(25^{\circ} \mathrm{C}\right)$. At each time interval, samples were removed, dried and weighed. The Swelling Index ( $\mathrm{Si} \%$ ) was calculated by Equation (1):

$$
\operatorname{Si}(\%)=\frac{(\text { Final weight }- \text { Initial weight })}{\text { Initial weight }} \times 100
$$

\section{Application of the $\mathrm{pH}$ indicator film}

The $\mathrm{pH}$ indicator film $\left(4 \mathrm{~cm}^{2}\right)$ was maintained in contact with ricotta sample (acquired in local market) and vacuum-packed into heat-shrinkable plastic bags and stored at $8^{\circ} \mathrm{C}$ for 7 days. After color changes occurred in the $\mathrm{pH}$ indicator film, samples were evaluated for $\mathrm{pH}$ and mesophilic microorganism counts. The $\mathrm{pH}$ ( $\mathrm{pH}$ meter T-100 Tekna, DM22-Digimed, São Paulo, SP, Brazil) was determined by introducing the electrode directly in the sample, and microbiological analyses were performed. Mesophilic microorganism was enumerated on PCA plates and incubated at $35^{\circ} \mathrm{C}$ for 48 hours.

\section{Results and discussion}

\section{Thickness and swelling index}

The film produced from chitosan/gelatin/PVA blend incorporated red cabbage extract were homogeneous, transparent, colored light brown and average thickness of $0.07 \pm 0.01 \mathrm{~mm}$. The period of hydration of the indicator film was ten minute (Figure 1). After this time, swelling index was not evaluated, due to erosion of the film not observed an equilibration period of hydration and a reduced mass. The behavior could be attributed the hydrophobicity of the polymers and with reorientation of polar functional groups toward to the top surface of the blend films..$^{15}$ Perreira Jr et al. ${ }^{10}$ recorded maximum hydration period of 3minutes for Chitosan/PVA/Anthocyanin films, after this time, a reduced mass was observed. This behavior is attributed to the chains attached by cross linking the polymer blend, since they lose their mobility after a period of hydration, hindering the access of solvent and consequently the hydration of the film. Other factor can be contributed to this behavior is the cross linking promoted by tripolyphosphate that promotes an interaction between the hydroxyl hydrogen and oxygen from the chitosan pyranosidic ring, causing a reduction in the number of hydrogen bonds to water.

\section{Application of the indicator film}

The indicator film color was initially light brown. After seven days of refrigeration storage, it was not observed visible change in the film indicator color (Figure 2). These results may be associated with maintenance of $\mathrm{pH}(4.48)$ and viable numbers of mesophilic microorganism (7 cycles logarithms) when compared with initial time. Thus, although the film is very sensitive to $\mathrm{pH}$ changes (data not shown), it cannot be applied to monitor Ricotta cheese spoilage caused by microbial contamination.

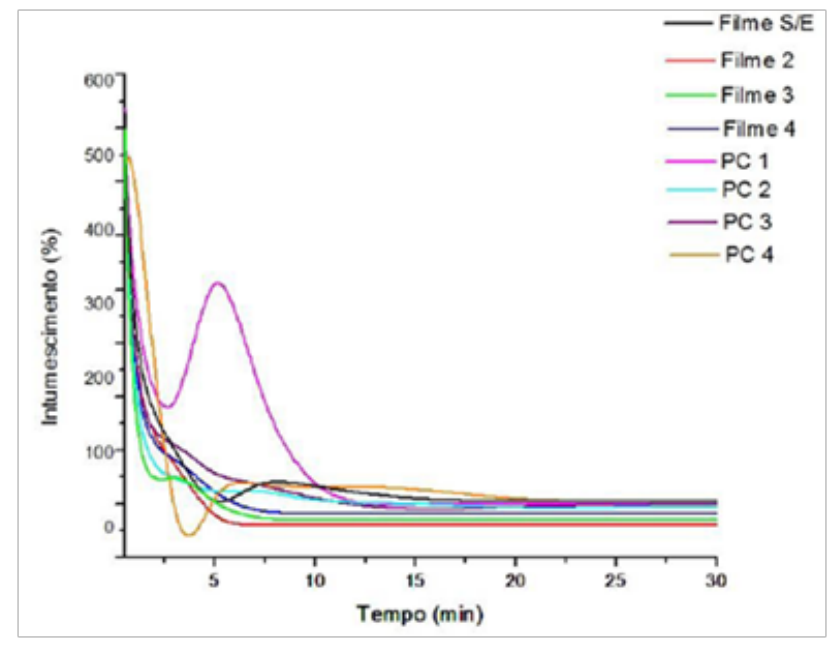

Figure I Hydration time and swelling index of indicator film (PC I). Swelling (\%)xTime (min).
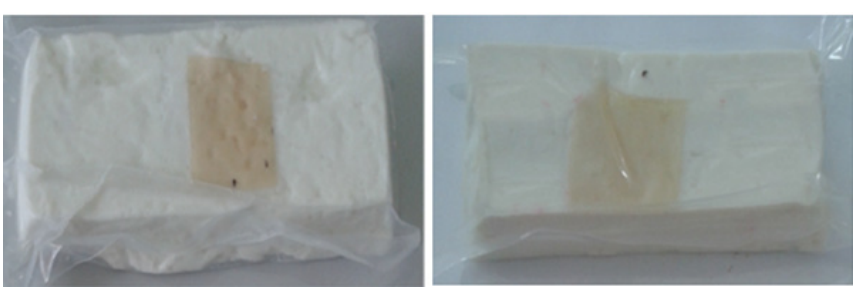

Figure 2 Color change of indicator film under refrigeration: (A) I day (B) 7days.

\section{Conclusion}

A biodegradable $\mathrm{pH}$ sensitive film was developed from renewable sources. In the proof-of-concept tests with Ricotta cheese, its applicability in this type of cheese was not possible. Further studies are necessary to evaluated the film potential to be applied as a smart food packaging.

\section{Acknwledgements}

None.

\section{Conflict fo interest}

The author declares no conflict of interest.

\section{References}

1. Realini CE, Marcos B. Active and intelligent packaging systems for a modern society. Meat Sci. 2014;98(3):404-419.

2. Benbettaïeb N, Karbowiak T, Brachais C, et al. Coupling tyrosol, quercetin or ferulic acid and electron beam irradiation to cross-link chitosan - gelatin films: A structure - function approach. European Polymer Journal. 2015;67:113-127.

3. Barbosa-Pereira L, Aurrekoetxea GP, Angulo I, et al. Development of 
new active packaging films coated with natural phenolic compounds to improve the oxidative stability of beef. Meat Sci. 2014;97:249-254.

4. Ditchfield C, Tadini CC, Santos p. Development and evaluation of a novel $\mathrm{pH}$ indicator biodegradable film based on cassava starch. Journal of Applied Polymer Science. 2010;120:1069.

5. Yoshida CMP, Bastos CEN, Franco TT. Modeling of potassium sorbate diffusion through chitosan films. LWT - Food Sci Technol. 2010;43(4):584 589.

6. Youssef AM, Abou-yousef H, El-sayed SM, et al. International journa of biological macromolecules mechanical and antibacterial properties of novel high performance chitosan/ nanocomposite films. Int $J$ Biol Macromol. 2015;76:25-32.

7. Leceta I, Peñalba M, Arana P, et al. Ageing of chitosan films : Effect of storage time on structure and optical, barrier and mechanical properties. European Polymer Journal. 2015;66:170-179.

8. Golasz LB, Botelho S. Film with anthocyanins as an indicator of chilled pork deterioration. Ciênc Tecnol Aliment. 2013;33(1):155-162.

9. Yoshida CMP, Maciel VB V, Mendonça MED, et al. Chitosan biobased and intelligent films: Monitoring $\mathrm{pH}$ variations. LWT - Food Sci Technol. 2014;55(1):83-89.
10. Pereira VA, de Arruda INQ, Stefani R. Active chitosan/PVA films with anthocyanins from Brassica oleraceae (Red Cabbage) as Time-temperature indicators for application in intelligent food packaging. Food Hydrocoll. 2014;43(1):180-188.

11. Silva-Pereira MC, Teixeira JA, Pereira-Júnior VA, et al. Chitosan/corn starch blend films with extract from Brassica oleraceae (red cabbage) as a visual indicator of fish deterioration. LWT - Food Sci Technol. 2015;61(1):258-262.

12. Di P, Sorrentino A, Mariniello L, et al. LWT - Food Science and Technology Chitosan/whey protein film as active coating to extend Ricotta cheese shelf-life. LWT - Food Sci Technol. 2011;44(10):2324-2327.

13. Hough G, Puglieso ML, Sanchez R, et al. Sensory and microbiological shelf-life of a commercial ricotta cheese. J Dairy Sci. 1999;82(3):454-459.

14. Science F. Quantitative methods for anthocyanins and degradation of total juice anthocyanin index for cranberry. J Food Sci. 1968;33(1):78-83.

15. Chen CH, Wang FY, Mao CF, et al. Studies of chitosan : II. Preparation and characterization of chitosan / poly (vinyl alcohol )/ gelatin ternary blend films. Int J Biol Macromol. 2008;3(1):37-42. 